\title{
Disk Battery as a Vaginal Foreign Body in a Five- Year-Old Preadolescent Child
}

\author{
Daniah Al-oufi ${ }^{1}$, Huwidah Mohammad Alkharboush ${ }^{1}$, Nadia Dawood Younis ${ }^{1}$, Ahmed Abu-Zaid ${ }^{2}$ \\ 1. Department of Obstetrics and Gynecology, East Jeddah General Hospital, Jeddah, SAU 2. College of Graduate Health \\ Sciences, The University of Tennessee Health Science Center, Memphis, USA
}

Corresponding author: Ahmed Abu-Zaid, aabuzaid@live.com

\begin{abstract}
The self-introduction of batteries into the vagina is exceedingly infrequent among preadolescents, with only six cases have been recorded in the English-language PubMed-indexed literature. Herein, we present the case of a five-year-old female child who presented with an 18-month history of recurrent ill-smelling vaginal discharge. Pelvic radiograph displayed a radio-opaque object, most likely representing a disk battery inside her vagina. Vaginoscopy showed a $1.2 \mathrm{~cm}$ disk battery that was removed from the right posterior vaginal fornix. Four weeks later, the child was doing well and symptom-free. Although rare, vaginal foreign bodies should be considered in the differential diagnosis in preadolescent girls presenting with chronic and recurrent vaginal discharge. Vaginoscopy is a useful tool diagnostically and therapeutically. A clinical summary of all PubMed-indexed cases of batteries as vaginal FBs in children is provided $(\mathrm{n}=6)$.
\end{abstract}

Categories: Obstetrics/Gynecology, Pediatrics

Keywords: vaginal fornix, foreign body, preadolescent child, vaginoscopy

\section{Introduction}

Vaginal foreign bodies (FBs) are unusual genital complaints. The estimated frequency of vaginal FB incidents is less than $5 \%$ in preadolescent females [1]. The vast majority of the cases take place between three and nine years of age [2]. The most frequently documented symptoms comprise vaginal discharge and bleeding $[1,3]$. A wide array of vaginal FBs has been described, such as nuts, stoppers, pencils, safety pins, and cloths. Nonetheless, clumped toilet paper is the most frequently encountered item in about $80 \%$ of all vaginal FB incidents [3]. The self-introduction of batteries into the vagina is exceedingly infrequent, with only six cases of batteries as vaginal FBs have been recorded in the PubMed-indexed literature [2-7]. Herein, we present the case of a five-year-old female child who had a disk battery lodged into the vagina.

\section{Case Presentation}

A five-year-old female child presented to our outpatient clinic with an 18-month history of recurrent illsmelling vaginal discharge. As reported by the mother, there was no apparent dysuria, hematuria, or

Review began 02/26/2021 Review ended 03/05/2021 Published 03/06/2021

\section{() Copyright 2021}

Al-oufi et al. This is an open access article distributed under the terms of the Creative Commons Attribution License CC-BY 4.0., which permits unrestricted use, distribution, and reproduction in any medium, provided the original author and source are credited. discomfort. The child was treated with repeated courses of antibiotics for vulvovaginitis; however, there was no substantial therapeutic response. Past medical and surgical histories were unremarkable.

On physical examination, the child was vitally stable and no signs of sexual abuse were suspected. Genital examination revealed erythema and excoriation around the vulva. The yellowish foul-smelling discharge was observed from the vaginal orifice. A digital rectal examination was not carried out. Cultures of the vaginal discharge demonstrated multi-drug resistant Escherichia coli. Subsequently, the child was admitted and started on intravenous cilastatin/imipenem for ten days. Laboratory investigations were notable only for a white blood cell count of 9200 cells/uL (normal range: 4000 to 11,000 cells/uL).

Pelvic radiograph displayed a radio-opaque object, most likely representing a disk battery FB at the lower part of the pelvic cavity. The exact anatomical position of the FB could not be pinpointed, however, the vagina was the most likely site of involvement (Figure 1). 


\section{Cureus}

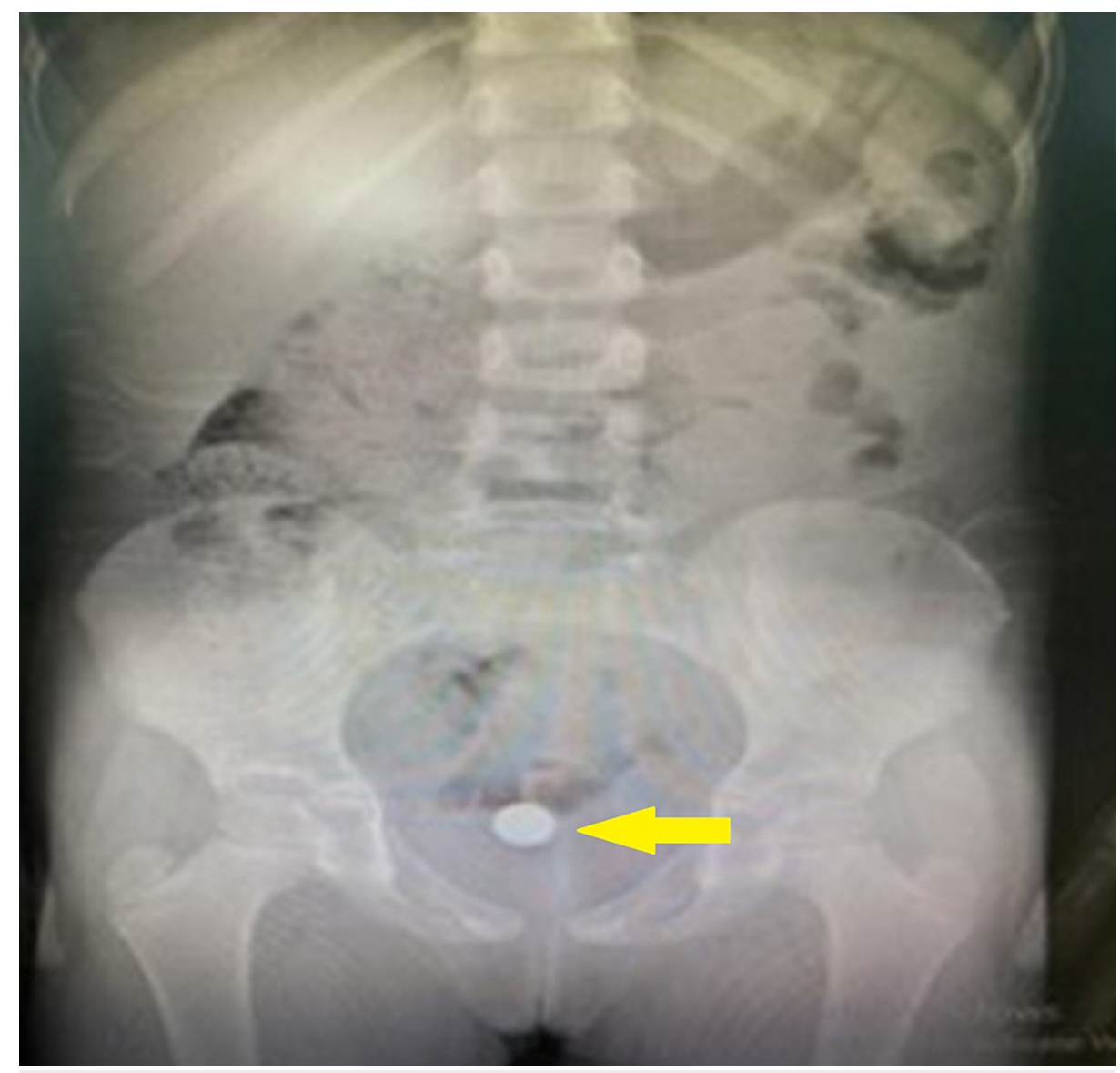

FIGURE 1: Pelvic radiograph showing a radio-opaque object (yellow arrow), most likely representing a disk battery foreign body at the lower part of the pelvic cavity (vagina).

The child underwent vaginoscopy. A $1.2 \mathrm{~cm}$ disk battery was removed from the right posterior vaginal fornix without active bleeding. The extracted disk battery had surrounding granulation tissue (Figure 2). The vagina was irrigated with saline several times afterward. 


\section{Cureus}

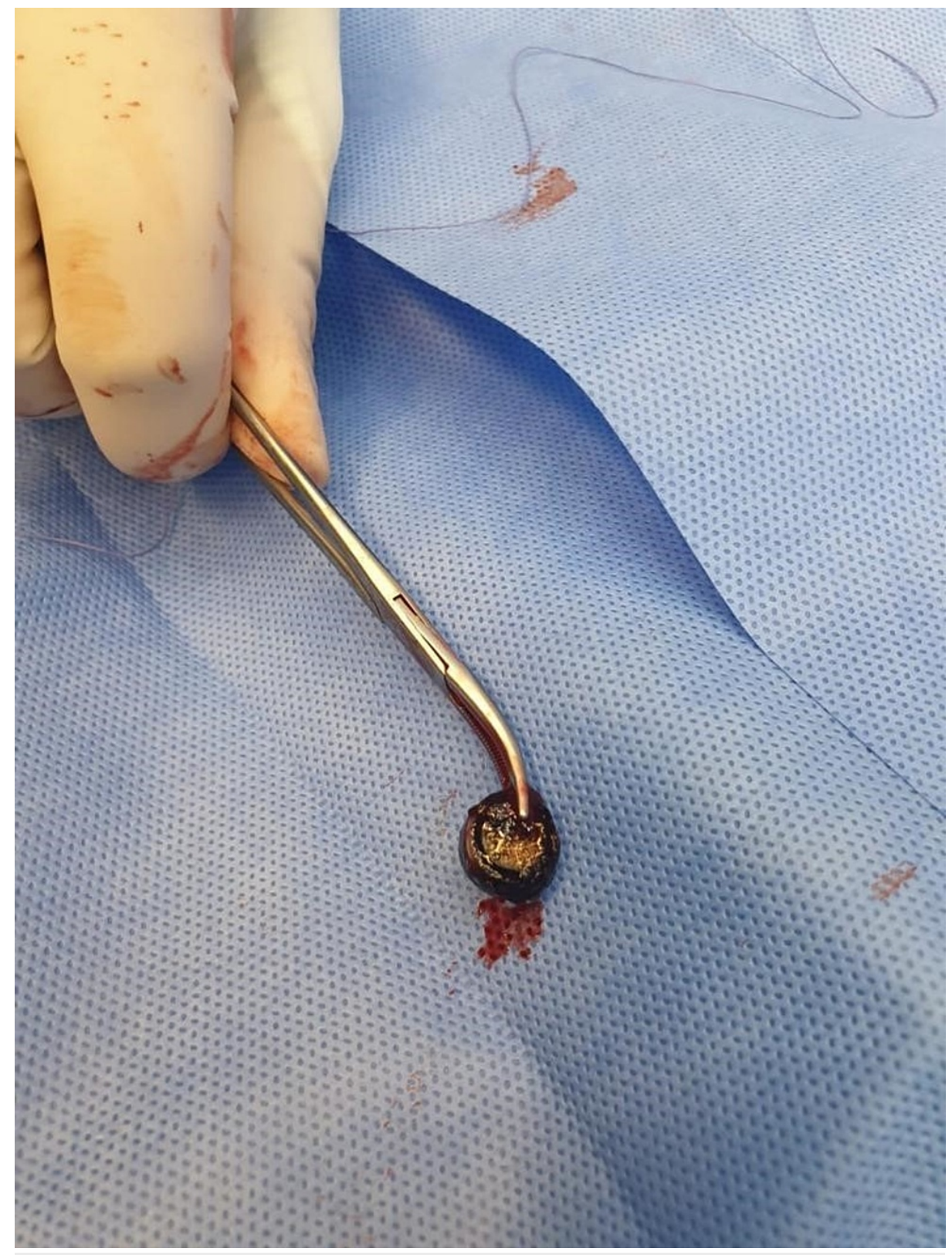

FIGURE 2: A $1.2 \mathrm{~cm}$ disk battery with granulation tissue and no bleeding was removed from the right posterior vaginal fornix during vaginoscopy.

After the completion of the in-patient course of cilastatin/imipenem antibiotics, the child was discharged home in good condition. At four weeks post-discharge, the child was seen in the outpatient clinic and she was doing well and symptom-free.

\section{Discussion}

Vaginal FBs are infrequent clinical encounters at pediatric outpatient clinics and emergency departments. Bundled pieces of toilet paper are the most frequent FB objects [3]. To the best of our knowledge, only six cases of batteries as vaginal FBs have been recorded in the English-language PubMed-indexed literature (Table 1) [2-7]. Our presented case is the seventh and it enriches the existing scarce literature. 


\section{Cureus}

\begin{tabular}{|c|c|c|c|c|c|c|c|c|c|c|}
\hline References & First author & Year & $\begin{array}{l}\text { Age } \\
\text { (year) }\end{array}$ & Symptoms & Duration & Imaging & $\begin{array}{l}\text { Battery } \\
\text { type }\end{array}$ & $\begin{array}{l}\text { Battery- } \\
\text { induced } \\
\text { damage }\end{array}$ & Management & Follow-up \\
\hline [4] & $\begin{array}{l}\text { Yanoh } \\
\text { and Yonemura }\end{array}$ & 2005 & 12 & $\begin{array}{l}\text { Fever of unknown } \\
\text { origin and lower } \\
\text { abdominal pain }\end{array}$ & 72 hours & $\begin{array}{l}\text { Radiography, } \\
\text { concomitant barium } \\
\text { enema and vaginography }\end{array}$ & Cylindrical & Uaginal & $\begin{array}{l}\text { Battery removal, necrotic } \\
\text { debridement, systemic antibiotics, } \\
\text { vaginal irrigation }\end{array}$ & $\begin{array}{l}8 \text { weeks, } \\
\text { symptom-free } \\
\text { and complete } \\
\text { healing }\end{array}$ \\
\hline [5] & Huppert et al. & 2009 & 13 & $\begin{array}{l}\text { Abdominal pain, } \\
\text { vaginal discharge, } \\
\text { and bleeding }\end{array}$ & 42 hours & $\begin{array}{l}\text { Cystoscopy, } \\
\text { vaginoscopy, } \\
\text { sigmoidoscopy }\end{array}$ & Cylindrical & $\begin{array}{l}\text { Necrotic } \\
\text { vaginal } \\
\text { burn }\end{array}$ & $\begin{array}{l}\text { Battery removal, oral pain killer, } \\
\text { topical estrogen, topical cortisone, } \\
\text { systemic antibiotics }\end{array}$ & $\begin{array}{l}3 \text { years, } \\
\text { symptom-free } \\
\text { and complete } \\
\text { healing }\end{array}$ \\
\hline [6] & Griffin et al. & 2015 & 8 & $\begin{array}{l}\text { Vaginal bleeding, } \\
\text { urinary retention, and } \\
\text { dysuria }\end{array}$ & 12 hours & $\begin{array}{l}\text { Sigmoidoscopy, } \\
\text { radiography }\end{array}$ & Disk & $\begin{array}{l}\text { Vaginal } \\
\text { burn }\end{array}$ & $\begin{array}{l}\text { antiemetic, topical estrogen, topical } \\
\text { antibiotics, systemic antibiotics }\end{array}$ & $\begin{array}{l}7 \text { days, } \\
\text { symptom-free } \\
\text { and complete } \\
\text { healing }\end{array}$ \\
\hline [7] & Semaan et al. & 2015 & 5 & $\begin{array}{l}\text { Vaginal discharge, } \\
\text { pelvic pain }\end{array}$ & 48 hours & $\begin{array}{l}\text { Vaginoscopy, } \\
\text { cystoscopy, rectoscopy }\end{array}$ & Disk & $\begin{array}{l}\text { Vaginal } \\
\text { burn }\end{array}$ & $\begin{array}{l}\text { Battery removal, topical estrogen, } \\
\text { systemic antibiotics }\end{array}$ & $\begin{array}{l}1 \text { year, } \\
\text { symptom-free, } \\
\text { complete } \\
\text { healing }\end{array}$ \\
\hline [2] & Khan et al. & 2016 & 2.5 & $\begin{array}{l}\text { history of self- } \\
\text { insertion of disk } \\
\text { battery }\end{array}$ & hours & $\begin{array}{l}\text { Radiography, } \\
\text { Vaginoscopy, } \\
\text { proctoscopy }\end{array}$ & Disk & $\begin{array}{l}\text { Vaginal } \\
\text { burn }\end{array}$ & $\begin{array}{l}\text { Battery removal, vaginal irrigation, } \\
\text { topical antibiotic }\end{array}$ & $\begin{array}{l}4 \text { weeks, } \\
\text { symptom-free } \\
\text { and complete } \\
\text { healing }\end{array}$ \\
\hline [3] & Nakib et al. & 2017 & 13 & Vaginal discharge & 6 years & $\begin{array}{l}\text { Radiography, ultrasound, } \\
\text { computed tomography, } \\
\text { vaginoscopy }\end{array}$ & Disk & $\begin{array}{l}\text { Vaginal } \\
\text { stenosis }\end{array}$ & $\begin{array}{l}\text { Battery removal, vaginal irrigation, } \\
\text { systemic antibiotics }\end{array}$ & $\begin{array}{l}1 \text { day, } \\
\text { symptom-free } \\
\text { and complete } \\
\text { healing }\end{array}$ \\
\hline Present & Al-oufi et al. & 2021 & 5 & Vaginal discharge & months & Radiography & Disk & $\begin{array}{l}\text { Vaginal } \\
\text { burn }\end{array}$ & $\begin{array}{l}\text { Battery removal, vaginal irrigation, } \\
\text { systemic antibiotics }\end{array}$ & $\begin{array}{l}4 \text { weeks, } \\
\text { symptom-free } \\
\text { and complete } \\
\text { healing }\end{array}$ \\
\hline
\end{tabular}

TABLE 1: A summary of all PubMed-indexed cases about batteries as vaginal foreign bodies.

In this series of batteries as vaginal FBs ( $\mathrm{n}=7$ ), the median age was eight years (range: $2.5-13$ years). This age of presentation is in harmony with the published literature in which the vast majority of vaginal FB cases take place between three and nine years of age [2].

Pelvic/abdominal pain $(n=4)$ and vaginal discharge $(n=4)$ were the most frequently reported symptoms, consistent with the published literature $[1,8]$. Generally, the presenting clinical manifestations largely depend on the dimension and nature of the introduced vaginal FBs. Additional potential presenting symptomatology of vaginal FBs comprises vaginal bleeding, genital itching, vulvar erythema, and dysuria $[1,8]$. Five and two cases had disk and cylindrical type batteries inserted into the vagina, respectively.

It is technically challenging to precisely determine the timeline of vaginal FB occurrence as children may not be able to narrate the history. Nevertheless, few children are smart enough to communicate losing something in their vagina. The duration of presenting complaints can be acute (within days) or chronic (for years). Nakib and colleagues reported the longest duration of six years for a disk-type battery FB lodged into the vagina of a pubescent girl [3]. The short- and long-term residence of lithium/alkaline batteries in the vagina causes battery-induced injuries of the vagina [4]. Such injuries include vaginal ulcerations, burns, fistulas, adhesions, and stenosis [2-7]. Literature review of Table 1 showed that battery-induced physical damages included only burn, ulceration, and stenosis. It appears that the duration of the inserted foreign body affected the type of battery-induced damage; vaginal burn and ulceration occurred acutely whereas stenosis occurred chronically.

Child abuse, urinary tract infection, vaginitis, and vulvitis are possible differential diagnoses in preadolescent children presenting with vaginal discharge [7]. History taking, physical examination, laboratory testing, and imaging modalities are all equally beneficial in ascertaining the most likely 
diagnosis. The genital examination usually takes place under general anesthesia in consideration of the young age group of children with vaginal FBs. Imaging most often portrays the vaginal FBs. Radio-opaque objects can be easily visualized through radiographs. The selection of imaging modality-namely radiograph, computed tomography, and magnetic resonance imaging-varies and is governed by several factors, one of which is the patient's age and presenting complaints. In our case, a radiograph was adequate to localize the vaginal FB at the lower part of the pelvic cavity. Vaginoscopy under general anesthesia is a useful diagnostic and therapeutic tool in adolescent children with suspected vaginal FBs [8]. Systemic antibiotics are often recommended and administered [3-7].

Potential complications that can occur if the vaginal FB is missed and not removed in time include vaginal ulcerations, burns, vesicovaginal fistulas, adhesions, and stenosis [2-7]. None of the reviewed cases of batteries as vaginal FBs in children resulted in vesicovaginal fistulas (Table 1). In fact, vesicovaginal fistulas are frequently caused by obstructed labor and following gynecological surgery [9]. While vesicovaginal fistulas occasionally can occur secondary to underlying malignancies, they rarely take place secondary to vaginally inserted FBs [9]. Nonetheless, several cases of vesicovaginal fistulas have been reported in literature among adults (more than 18 years old) [10-13].

\section{Conclusions}

In summary, the self-introduction of batteries as FBs into the vagina is exceedingly infrequent. However, it should be considered in the differential diagnosis in preadolescent girls presenting with chronic and recurrent vaginal discharge. Failure to remove the vaginal FBs early can result in unfavorable acute and chronic complications, such as vaginal ulcerations, burns, vesicovaginal fistulas, adhesions, and stenosis. Vaginoscopy is a useful tool diagnostically and therapeutically in the management of vaginal FBs.

\section{Additional Information}

\section{Disclosures}

Human subjects: Consent was obtained or waived by all participants in this study. Conflicts of interest: In compliance with the ICMJE uniform disclosure form, all authors declare the following: Payment/services info: All authors have declared that no financial support was received from any organization for the submitted work. Financial relationships: All authors have declared that they have no financial relationships at present or within the previous three years with any organizations that might have an interest in the submitted work. Other relationships: All authors have declared that there are no other relationships or activities that could appear to have influenced the submitted work.

\section{References}

1. Paradise JE, Willis ED: Probability of vaginal foreign body in girls with genital complaints . Am J Dis Child. 1985, 139:472-476. 10.1001/archpedi.1985.02140070046031

2. Khan YA, Mahmood M, Taqi E: Disc battery - an unusual vaginal foreign body in a child . APSP J Case Rep. 2016, 7:29. 10.21699/ajcr.v7i4.467

3. Nakib G, Calcaterra V, Pelizzo G: Longstanding presence of a vaginal foreign body (battery): severe stenosis in a 13-year-old girl. J Pediatr Adolesc Gynecol. 2017, 30:15-18. 10.1016/j.jpag.2016.08.015

4. Yanoh K, Yonemura Y: Severe vaginal ulcerations secondary to insertion of an alkaline battery . J Trauma. 2005, 58:410-412. 10.1097/01.ta.0000068993.90723.46

5. Huppert J, Griffeth S, Breech L, Hillard P: Vaginal burn injury due to alkaline batteries . J Pediatr Adolesc Gynecol. 2009, 22:133-136. 10.1016/j.jpag.2008.10.009

6. Griffin K, Brent R, Vollenhoven B, Swanson AE: Vaginal burn from alkaline battery in an 8-year-old . J Pediatr Adolesc Gynecol. 2015, 28:99-100. 10.1016/j.jpag.2014.08.010

7. Semaan A, Klein T, Vahdad MR, Boemers TM, Pohle R: Severe vaginal burns in a 5-year-old girl due to an alkaline battery in the vagina. J Pediatr Adolesc Gynecol. 2015, 28:147-148. 10.1016/j.jpag.2014.12.001

8. Stricker T, Navratil F, Sennhauser FH: Vaginal foreign bodies. J Paediatr Child Health. 2004, 40:205-207. 10.1111/j.1440-1754.2004.00338.x

9. Hilton P: Vesico-vaginal fistulas in developing countries . Int J Gynaecol Obstet. 2003, 82:285-295. 10.1016/s0020-7292(03)00222-4

10. Massinde A, Kihunrwa A: Large vesico-vaginal fistula caused by a foreign body . Ann Med Health Sci Res 2013, 3:456-457. 10.4103/2141-9248.117934

11. Chapman GW, Jr: An unusual intravaginal foreign body. J Natl Med Assoc. 1984, 76:811-812.

12. Puppo A, Naselli A, Centurioni MG: Vesicovaginal fistula caused by a vaginal foreign body in a 72-year-old woman: case report and literature review. Int Urogynecol J Pelvic Floor Dysfunct. 2009, 20:1387-1389. 10.1007/s00192-009-0877-y

13. Sinha A, Olah KS: Vesicovaginal fistula caused by a foreign body: delayed presentation and repair with martius graft. J Obstet Gynaecol. 2005, 25:223-224. 10.1080/01443610500051395 